\title{
Multiple duodenal polyps in uraemia: a little known clinical entity
}

\author{
H PAIMELA, L G TALLGREN, S STENMAN, H v NUMERS, AND T M SCHEININ \\ From the Fourth Departments of Surgery and of Medicine, Helsinki University Central Hospital and \\ Department of Pathology, University of Helsinki, Helsinki, Finland
}

SUMmaRY Multiple duodenal polyps were found by endoscopy in five out of 33 patients with chronic renal failure and in one of 300 controls. In the uraemic cases the polyps were caused by circumscribed nodular hyperplasia of Brunner's glands. One of these five patients later underwent surgery for duodenal obstruction caused by the polyps; the other patients were asymptomatic. One of the controls had multiple duodenal polyps. The recorded incidence of multiple duodenal polyps was significantly higher among patients with chronic renal failure than in patients without renal disease. Patients with chronic renal failure and polyps did not differ significantly from the other renal patients in the comparison of variables such as gastric acid secretion, serum concentrations of gastrin and group I pepsinogens or mean length of dialysis treatment. The mean $\mathrm{pH}$ of gastric resting juice was significantly higher, however, in uraemic patients with polyps than in those without. Uraemic patients displayed a gastric acid secretion capacity within normal range, and significantly raised serum gastrin and group I pepsinogen concentrations.

Various functional and morphological alterations of the gastrointestinal tract have been described in patients with uraemia. ${ }^{12}$ The excretion of urea into the gastrointestinal lumen has been considered a specific feature of these patients. ${ }^{3}$ Furthermore, these patients have raised serum concentrations of group I pepsinogens ${ }^{4-6}$ and gastrin..$^{7-10}$ Gastric acid secretion is either normal or increased..$^{11-14}$

The lesions in the upper gastrointestinal tract ascribed to uraemia are mucosal oedema and haemorrhage of varying degrees. ${ }^{15} 16$ Radiological observations of prominent mucosal folds, suggestive of polyposis, in the duodenum have been described, ${ }^{17-19}$ but the association of duodenal polyposis with uraemia has not been sufficiently clinically documented. Duodenal polyps are encountered in $0.9 \%$ of all consecutive patients referred for upper gastrointestinal endoscopy. ${ }^{20}$ As early as 1934, however, Feyrter in his classical study of the pathology of Brunner's gland hyperplasia in a series of 2800 consecutive autopsies, found 40 cases of hyperplasia of Brunner's glands. ${ }^{21}$ A scrutiny of

Address for correspondence: Dr H Paimela, Fourth Department of Surgery, University Central Hospital of Helsinki, Kasarmikatu 11-13, SF-00130 Helsinki 13, Finland.

Received for publication 31 May 1983 his data reveals that 22 of these patients had been uraemic. This observation has not received clinical attention.

We report here five cases of Brunner's gland hyperplasia among 33 consecutive uraemic patients referred for endoscopy as a routine upper gastrointestinal evaluation before undergoing renal transplantation.

\section{Methods}

PATIENTS

Thirty three consecutive patients (14 women and 19 men) were studied during the course of a project focusing on upper gastrointestinal lesions in uraemia, mean age was 42.6 years (range 15-68 years). Twenty three patients had been on regular haemodialysis for an average of 6.8 months. Ten patients not yet being dialysed. The concentration of serum creatinine was $771 \pm 38 \mu \mathrm{mol} / 1$ (mean \pm SEM) with a range of $458-1484 \mu \mathrm{mol} / \mathrm{l}$ in the whole group and $847 \pm 48 \mu \mathrm{mol} / \mathrm{l}$ and $559 \pm 26$ $\mu \mathrm{mol} / \mathrm{l}$ respectively in dialysed and non-dialysed patients. None of these patients was treated or had been previously treated with immunosuppressive drugs or corticosteroids. 
The control group consisted of 300 patients (123 women and 177 men) with normal kidney function. They were selected from patients referred for upper gastrointestinal endoscopy, and matched for age and sex with the renal patients. The mean age of the controls was $47 \cdot 2$ years (range 18-66 years).

Thirty three patients with uncomplicated duodenal ulcer ( 12 women and 21 men) and with normal renal function served as a reference group in respect to gastric acid secretion and to the serum concentrations of gastrin and group I pepsinogens. Their mean age was $46 \cdot 7$ years. They were randomly selected from patients attending for surgical treatment of duodenal ulcer.

All patients with renal failure were examined by fibreoptic endoscopy, tissue specimens for histological study were obtained by forceps biopsy. Both the renal and the duodenal ulcer patients were studied for gastric acid secretion and for serum concentrations of gastrin and group I pepsinogens. Serum creatinine concentrations were determined in all patients. All the procedures in this work were in accordance with the ethical standards of the Helsinki Declaration of 1975.

Gastric acid secretion tests were performed by gastric intubation and suction as described by Baron. ${ }^{22}$ Gastric juice was collected in 15 minute fractions using a special pump (Egnell, Ameda, Switzerland). Basal acid output was determined during the first hour. For determination of peak acid output the patients were given pentagastrin (Peptavlon $^{\mathrm{R}}$, ICI, England) $6 \mu \mathrm{g} / \mathrm{kg}$ body weight intramuscularly, and gastric juice was collected during the following hour. The acid concentration of gastrin and group I pepsinogens were determined by radioimmunoassay. ${ }^{23}$ In the latter method lactoperoxidase sorbent was used to iodinate pepsinogen I, and a double antibody solid phase (DASP) technique to separate the bound and free fraction in radioimmunoassay. The blood samples for the determinations were collected immediately before the acid secretion test. The reference range in healthy subjects for gastrin was 5-50 pmol/l and for group I pepsinogens $50-150 \mu \mathrm{g} / \mathrm{l}$.

Student's $t$ test and $\chi^{2}$ test were used for the calculation of statistical significances.

\section{Results}

Between 10 and 20 multiple polyps were found in the duodenum in five out of 33 patients with renal failure $(15 \cdot 2 \%$, two women and three men). The polyps were located in the duodenal bulb and in the descending part of the duodenum above the papilla of Vater. The diameter of the polyps was less than $5 \mathrm{~mm}$ in four patients. In one patient the largest polyps were over $10 \mathrm{~mm}$ in diameter, and he had to be treated surgically for symptoms due to obstruction caused by the polyps (Fig. 1).

Endoscopic forceps biopsies were obtained from all patients and open surgical biopsy from the patient operated on for obstruction (Fig. 2). In the surgical specimen, hyperplastic Brunner gland tissue was located in the submucosa. It had cystically enlarged ducts and acini, and numerous fibrous or smooth muscle septa transversed the stroma. The duodenal villi were slightly atrophic above these glandular structures.

Duodenal polyps were also found in two control patients $(0.7 \%)$. One had a solitary polyp and the other a mild form of polyposis with multiple small mucosal rises in the duodenal bulb. Histological specimens were not taken. The increased occurrence of multiple duodenal polyps among azotaemic patients as compared with the controls was statistically significant $(p<0 \cdot 05)$.

Patients with multiple duodenal polyps did not differ significantly from the other patients with renal failure with regard to basal and stimulated gastric acid secretion capacities or to serum concentrations of gastrin and group I pepsinogens or to the length of time of dialysis treatment. The $\mathrm{pH}$ of gastric resting juice, however, was significantly higher in the polyp patients than in the other uraemic patients $(p<0.05)$ (Table 1).

The acid secretion capacity among the renal patients was significantly lower than among the

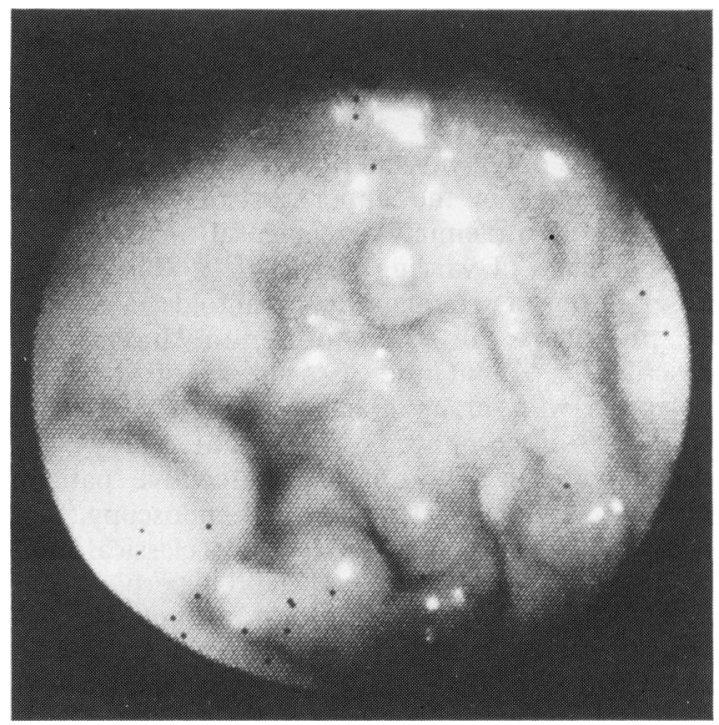

Fig. 1 Endoscopic finding of the duodenum of uraemic patient with multiple duodenal polyps causing obstruction. 


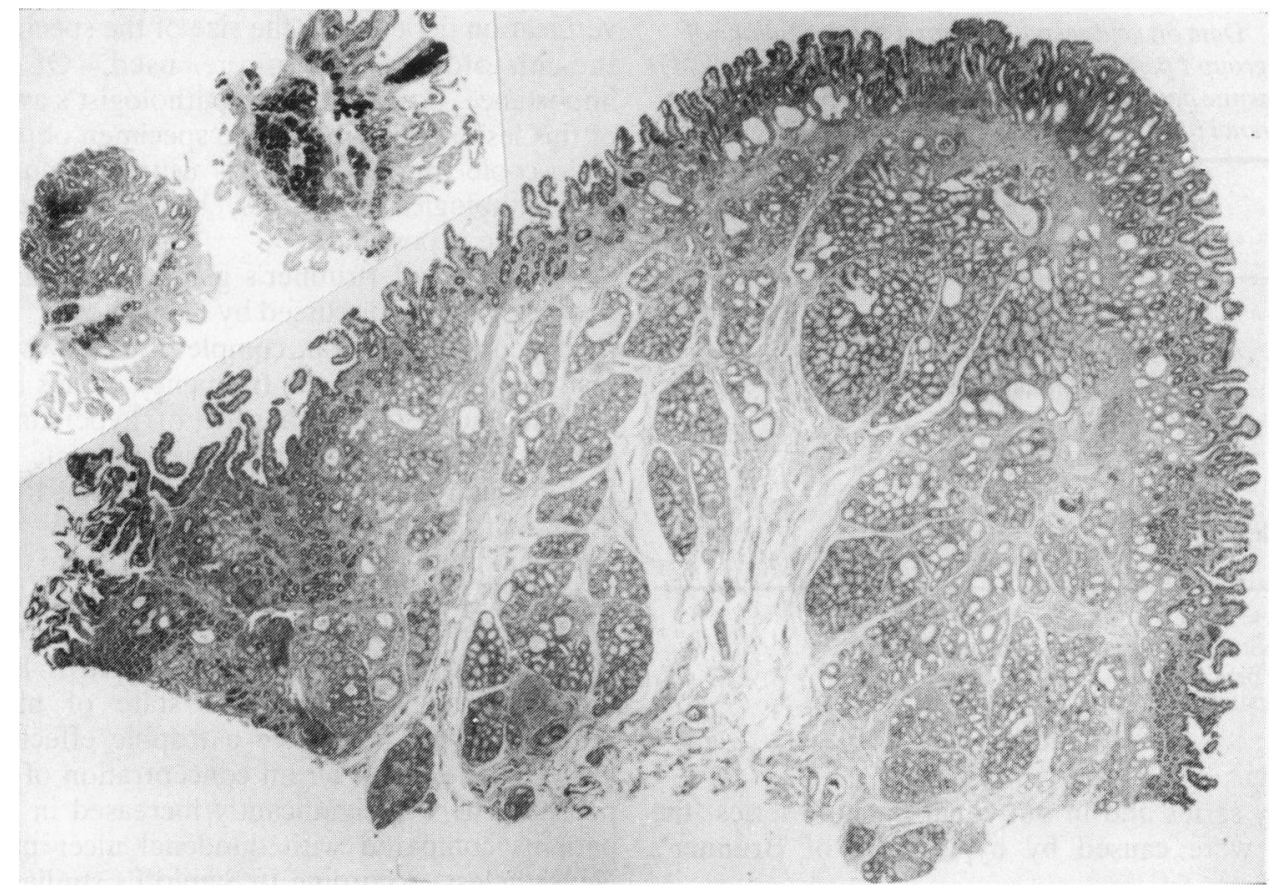

Fig. 2 Surgically removed hyperplastic Brunner's gland and two specimens obtained by forceps biopsy (insert). All histological preparations used in this study were made from paraffin-embedded material by staining 4-6 um thick sections with van Gieson's stain and alcian blue PAS. Characteristic changes in the hyperplastic gland: enlarged size, cystically dilated ducts, numerous fibrous or smooth muscle septa traversing stroma, and slight villus atrophy of overlying mucosa. Orig. mag $\times 15$.

Table 1 Data on acid secretion, serum concentrations of gastrin, group I pepsinogens and creatinine (mean \pm SEM) in uraemic patients with multiple duodenal polyps and in uraemic patients with endoscopically normal duodenum

\begin{tabular}{lll}
\hline & $\begin{array}{l}\text { Patients with } \\
\text { polyps } \\
n=5 \\
\text { (range) }\end{array}$ & $\begin{array}{l}\text { Patients without } \\
\text { polyps } \\
n=28 \\
\text { (range) }\end{array}$ \\
\hline Variable & $6 \cdot 9 \pm 1 \cdot 3$ & $4 \cdot 4 \pm 0 \cdot 5 \S$ \\
pH of gastric & $(2 \cdot 1-9 \cdot 0)$ & $(1 \cdot 7-8 \cdot 0)$ \\
resting juice & $0 \cdot 9 \pm 0 \cdot 6$ & $1 \cdot 1 \pm 0 \cdot 3 \|$ \\
BAO* & $(0-2 \cdot 9)$ & $(0-8 \cdot 9)$ \\
$\left(\mathrm{mEq}^{*} / \mathrm{h}\right)$ & $8 \cdot 6 \pm 5 \cdot 2$ & $21 \cdot 5 \pm 2 \cdot 9 \|$ \\
PAO & $(0-26 \cdot 9)$ & $(0-71 \cdot 0)$ \\
(mEq/h) & $200.0 \pm 93 \cdot 9$ & $102 \cdot 1 \pm 32 \cdot 3 \|$ \\
S-gastrin & $(56-560)$ & $(32-909)$ \\
$($ pmol/) & $224 \cdot 4 \pm 40 \cdot 5$ & $255 \cdot 7 \pm 33 \cdot 0 \|$ \\
S-PG I $\neq$ & $(150-360)$ & $(49-606)$ \\
$(\mu / 1)$ & $737 \cdot 2 \pm 103 \cdot 1$ & $777 \cdot 4 \pm 42 \cdot 0 \|$ \\
S-creatinine & $(534-1121)$ & $(458-1484)$ \\
$(\mu \mathrm{mol} / \mathrm{l})$ & &
\end{tabular}

* basal acid output

$\dagger$ pentagastrin stimulated peak acid output

$\ddagger$ group I pepsinogens

$\$ 0.05>p>0.02$

$\| p>0.05$ duodenal ulcer patients both under basal conditions and after stimulation with pentagastrin $(\mathrm{p}<0.01)$. The serum concentrations of group I pepsinogens and gastrin were significantly higher among renal patients than among the duodenal ulcer patients ( $\mathrm{p}<0.01$ and $<0.05$, respectively) (Table 2 ).

\section{Discussion}

The necropsy incidence of benign tumours of the small intestine has been reported to be $0.16 \% .{ }^{24}$ Of these $18 \%$ were located in the duodenum. Five per cent of benign duodenal tumours were stated to be lesions of Brunner's glands. ${ }^{25}$

The frequency of patients with duodenal polyps encountered at routine upper gastrointestinal endoscopy has been reported to be $0.9 \%$. $^{20}$ In Feyrter's autopsy series it was $1 \cdot 2 \% .^{21}$ These figures are in agreement with the findings of the present control series $(0.7 \%)$. The overall frequency of multiple duodenal polyps has not been reported until now. In our control series it was $\mathbf{0 . 3 \%}$. In the present series of 33 patients with chronic renal failure the occurrence of multiple duodenal polyps was significantly higher (15.2\%). Both in Feyrter's 
Table 2 Data on acid secretion, serum concentrations of gastrin, group I pepsinogens and creatinine (mean \pm SEM) in all uraemic patients and in duodenal ulcer patients with normal renal function

\begin{tabular}{lll}
\hline Variable & $\begin{array}{l}\text { Uraemic patients } \\
n=33 \\
\text { (range) }\end{array}$ & $\begin{array}{l}\text { DU patients } \\
n=30 \\
\text { (range) }\end{array}$ \\
\hline BAO* $^{*}$ & $1 \cdot 1 \pm 0 \cdot 3$ & $2 \cdot 7 \pm 0 \cdot 4 \|$ \\
$(\mathrm{mEq} / \mathrm{h})$ & $(0-8 \cdot 9)$ & $(0-9 \cdot 8)$ \\
PAO $_{\mathrm{Pg}}^{\dagger}$ & $19 \cdot 5 \pm 2 \cdot 7$ & $30 \cdot 2 \pm 2 \cdot 5 \|$ \\
$(\mathrm{mEq} / \mathrm{h})$ & $(0-49 \cdot 8)$ & $(7 \cdot 5-61 \cdot 0)$ \\
S-gastrin & $117.4 \pm 30 \cdot 9$ & $47 \cdot 1 \pm 6 \cdot 48$ \\
(pmol/) & $(32-909)$ & $(18-220)$ \\
S-PG I & $250 \cdot 1 \pm 27 \cdot 9$ & $128 \cdot 6 \pm 14 \cdot 4 \|$ \\
$(\mu \mathrm{g} / \mathrm{l})$ & $(49-606)$ & $(42-298)$ \\
S-creatinine & $771 \cdot 3 \pm 38 \cdot 4$ & $77 \cdot 3 \pm 4 \cdot 1 \|$ \\
$(\mu \mathrm{mol} / \mathrm{n})$ & $(458-1484)$ & $(58-95)$ \\
\hline
\end{tabular}

* basal acid output

$\dagger$ pentagastrin stimulated peak acid output

$\ddagger$ group I pepsinogens

$\S 0.05>\mathrm{p}>0.02$

$\| \mathbf{p}<0.01$

autopsy series and in our renal patients series, the polyps were caused by hyperplasia of Brunner's glands.

In Feyrter's autopsy series ${ }^{21} 55 \%$ of the cases with Brunner's gland hyperplasia had had uraemia. Radiological evidence for morphological alterations consistent with Brunner's gland hyperplasia appearing more frequently among uraemic patients than among control patients has been previously reported by Wiener et al ${ }^{19} 1969$, Dorph et al ${ }^{17}$ and Lewicki et $^{18}{ }^{18} 1972$. Similar observations have been reported in the endoscopic series by Muolo et $a^{26}$ 1979 , with histological verification. The incidence of Brunner's gland hyperplasia in uraemic patients in their series was $21.8 \%$ as compared with $15.2 \%$ in our series, verified histologically.

Brunner's glands are mostly located in the first part of the duodenum, but they may extend a short distance into the pylorus or distally occasionally even into the first part of the jejunum. ${ }^{27}$ Brunner's gland hyperplasia can be classified into three different forms according to Feyrter: ${ }^{21}$ (1) diffuse nodular hyperplasia, in which numerous sessile projections are found throughout the duodenum; (2) circumscribed nodular hyperplasia, in which sessile projections are to be found in the first portion of the duodenum; and (3) adenoma of Brunner's gland, in which a polypoid tumour like projection is found in the duodenum. In Feyrter's series the first two types were the commonest. In the present series all cases were of the second type.

The diagnosis of Brunner's gland hyperplasia is primarily based on histology, as well as on endoscopic and radiologic findings. Histological verification depends on the size of the specimen and the histological technique used. Of utmost importance, however, is the pathologist's awareness of this lesion. The size of the specimen obtained by endoscopic forceps biopsy is usually adequate for histopathological diagnosis, but snare-excision is preferable if possible.

The causes of Brunner's gland hyperplasia have been thoroughly discussed by Kaplan et al, ${ }^{28}$ but the pathogenesis is so far completely unknown. The manifold increase in the frequency of this lesion in uraemia suggests that a state of hyperstimulation occurs in uraemia. In this series uraemic patients had a mean gastric acid secretion capacity within normal range and significantly lower than in duodenal ulcer patients. Thus an increased acid load on the duodenal mucosa does not explain the development of Brunner's gland hyperplasia in these patients. Although raised gastrin levels in uraemia may only reflect a state of metabolic retention, they may have a trophic effect on the mucosa. The mean serum concentration of group I pepsinogens was significantly increased in uraemic patients compared with duodenal ulcer patients. ${ }^{5}$ Nevertheless, according to Samloff's studies on the cellular origin of group I and II pepsinogens, ${ }^{29} 30$ which show that the latter pepsinogens originate in Brunner's glands, it would be expected that a disturbed metabolism of group II pepsinogens associates with the described submucosal alteration. This is supported by the electronmicroscopical observation that cells of Brunner's glands contain homogeneous granules, as do zymogen cells. These contain only group II pepsinogens, unlike the chief cells of the stomach which contain both pepsinogens. ${ }^{31} 32$ Other pathogenetic mechanisms connected to the function of secretory ducts of Brunner's glands may also exist.

The most important clinical features in hyperplasia of Brunner's glands are bleeding and obstruction. Epigastric distress, vomiting and diarrhoea are also encountered in patients with these lesions. ${ }^{28}$ Most patients are, however, asymptomatic as in our series.

The treatment of Brunner's gland hyperplasia is conservative as these lesions are considered benign ${ }^{33}{ }^{34}$ but lesions causing obstruction or upper gastrointestinal bleeding should be removed endoscopically or by transduodenal excision. If they cause obstruction and cannot be removed with safety, a duodenal bypass must be made (gastrojejunostomy) to which a vagotomy should be added if gastric acid hypersecretion has been shown.

This work has been supported financially by Finska Läkaresällskapet and the Sigrid Jusélius foundation. 


\section{References}

1 Black D, Jones NF. Chronic renal failure. In: Black D, Jones NF, eds. Renal disease. Oxford: Blackwell, 1979.

2 Merrill JP, Hampers CL. Uremia (First of two parts). $N$ Engl J Med 1970; 282: 953-60.

3 Lieber CS, Lefevre A. Ammonia as a source of gastric hypoacidity in patients with uremia. J Clin Invest 1959; 38: 1271-7.

4 Lalla M, Räsänen V. The effect of renal transplantation on serum group I pepsinogens as measured by radioimmunoassay. J Clin Chem Clin Biochem 1980; 18: 688 .

5 Samloff IM, Liebman WM, Panitch NM. Serum group I pepsinogens by radioimmunoassay in control subjects and patients with peptic ulcer. Gastroenterology 1975; 69: 83-90.

6 Swamy AP, Mangla JC, Cestero RVM, Guarasci G. Serum pepsinogens and gastrins in chronic hemodialysis patients. Biochem Med 1981; 25: 227-33.

7 Gokal R, Kettlewell M, Drexler E, Oliver DO, Morris PJ. Gastrin levels in chronic renal failure, hemodialysis and renal transplant patients. Clin Nephrol 1980; 14: 96-7.

8 Korman MG, Laver MC, Hansky J. Hypergastrinemia in chronic renal failure. $\mathrm{Br}$ Med J 1972; 1: 209-10.

9 Sullivan SM, Tustanoff E, Slaughter DN, Linton AL, Lindsay RM, Watson WC. Hypergastrinemia and gastric acid hypersecretion in uremia. Clin Nephrol 1976; 5: 25-8.

10 Tani N, Harasawa S, Suzuki S et al. Lesions of the upper gastrointestinal tract in patients with chronic renal failure. Gastroenterol Jpn 1980; 15: 480-4.

11 Ala-Kaila M, Kataja M, Keyriläinen O, Pasternack A. The gastric secretion profile of patients with chronic renal failure. Ann Clin Res 1981; 13: 65-70.

12 Chisholm GD, Mee AD, Williams G, Castro JE, Baron JH. Peptic ulceration, gastric secretion, and renal transplantation. Br Med J 1977; 25: 1630-3.

13 Doherty CC. Gastric secretion in chronic uremia and after renal transplantation. Ir J Med Sci 1980; 149: 5-9.

14 Gold CH, Morley JL, Viljoen M, Tim LO, de Forseca M, Kalk WJ. Gastric acid secretion and serum gastrin levels in patients with chronic renal failure on regular hemodialysis. Nephron 1980; 25: 92-5.

15 Jaffe RH, Laing DR. Changes of the digestive tract in uremia. Arch Intern Med 1934; 53: 851-64.

16 Mason EE. Gastrointestinal lesions occurring in uremia. Ann Intern Med 1952; 37: 96-105.
17 Dorph S, Oigaard A, Pederson G, McNair A, Sorenson MB. Gastroduodenal mucosal changes in chronic uremia. Scand J Gastroenterol 1972; 7: 589-92.

18 Lewicki AM, Saito S, Merrill JP. Gastrointestinal bleeding in the renal transplant patient. Radiology 1972; 102: 533-7.

19 Wiener SN, Vertes V, Shapiro H. The upper gastrointestinal tract in patients undergoing chronic dialysis. Radiology 1969; 92: 110-4.

20 Raftery MJ, Walters JM, Stevens FM, Little MPG, Crowe JP, McCarthy CF. Upper gastro-intestinal polyps - An endoscopic study. Ir Med J 1981; 74: 63-5.

21 Feyrter F. Über Wucherungen der Brunnerschen Drüsen. II. Teil der Beiträge zur Geschwulstlehre (nach Untersuchungen am menschlichen Darm). Virchows Arch [Pathol Anat] 1934; 293: 509-26.

22 Baron JH. The clinical application of gastric secretion measurements. Clin Gastroenterol 1973; 2: 293-315.

23 Yalow RS, Berson SA. Radioimmunoassay of gastrin. Gastroenterology 1970; 58: 1-14.

24 Machella TE. Tumours of the small intestine. In: Bockus HL, ed. Gastroenterology vol. II. Philadelphia, Saunders: 1964.

25 Botsford W, Crowe P. Tumors of the small intestine: review of 115 cases. Am J Surg 1962; 103: 358-65.

26 Muolo A, Ghidini O, Ancona G, et al. Gastroduodenal mucosal changes, gastric acid secretion and gastrin levels following successful kidney transplantation. Transplant Proc 1979; 11: 1277-9.

27 Ham A, Leeson TS. Histology. London: Pitman, 1961.

28 Kaplan EL, Dyson WL, Fitts WT. Hyperplasia of Brunner's glands of the duodenum. Surg Gynecol Obstet 1968; 126: 371-5.

29 Samloff IM. Cellular localization of group I pepsinogens in human gastric mucosa by immunofluorescence. Gastroenterology 1971; 61: 185-8.

30 Samloff IM, Liebman WM. Cellular localization of the group II pepsinogens in human stomach and duodenum by immunofluorescence. -Gastroenterology 1973; 65: $36-42$.

31 Rubin W, Rose LL, Sleisenger MH, Jeffries GH. The normal human gastric epithelia. A fine structural study. Lab Invest 1968; 19: 598-626.

32 Leeson TS, Leeson CR. The fine structure of Brunner's glands in man. $J$ Anat 1968; 103: 263-76.

33 Robertson HE. The pathology of Brunner's glands. Arch Pathol 1941; 31: 112-30.

34 Spellberg MA, Vucelic B. A case of Brunner's glands hyperplasia with diarrhea responsive to cimetidine. Am J Gastroenterol 1980; 73: 519-22. 